\title{
INNOVATIVE TOOLS FOR MANAGING HISTORICAL BUILDINGS: THE USE OF GEOGRAPHIC INFORMATION SYSTEM AND ONTOLOGIES FOR HISTORICAL CENTERS
}

\author{
M. Acierno ${ }^{1}$, D. Fiorani ${ }^{2}$ \\ ${ }^{1}$ Sapienza, Università di Roma, Dipartimento di Storia, Disegno e Restauro dell'Architettura, marta.acierno@uniroma1.it \\ ${ }^{2}$ Sapienza, Università di Roma, Dipartimento di Storia, Disegno e Restauro dell’Architettura, donatella.fiorani@ uniroma1.it
}

KEY WORDS: Historical centres, Risk Map, Ontology, Geographic Information System, Territory Information System

\begin{abstract}
:
A recent study and the digitalization of historical centres have developed a completely new strategy for the conservation management of urban buildings through the 'Risk Map' of MiBAC. Issues, aims and structure of the Territory Information System (TIS) have been wholly outlined in a dedicated book that describes the structure of the system, also following a historical framing of the debate and the previous experiences. The elaboration of a dedicated ontology adds the opportunity to make the same data available to other kind of software, beginning from HBIM Systems. This aim is pursued developing a special extension of CIDOC-CRM, an already consolidated ontology initially dedicated to the conservation issue of museums. The work has firstly considered the field of architectural conservation and recently further developed addressing historical centres. In this way, a synthetic description of the buildings, including the main features together with vulnerability and transformation index, will allow, through the 3D representation of the town, a stable monitoring of the urban tissue, constantly up to date with the new data deriving from the interventions gradually realized.
\end{abstract}

\section{RISK MAP}

\subsection{General frame}

In a way, the 'Risk Map' has been a victim of the success of its definition, at least in Italy. The original Italian name 'Carta del Rischio' appeared for the first time in connection with a new Geographic Information System defined at the beginning of last Ninetieth by the Istituto Centrale del Restauro (now Istituto superiore per la Conservazione ed il Restauro), of the Ministry of Cultural Heritage and Activity (Carta del Rischio 1996; Castelli, 1997).

Tool and denomination were accurately defined on the base of the task and the conformation of the digital system; the new digital platform, for the first time, allowed to relate some different maps of the territory of the peninsula with the information about the nature and the state of conservation of single buildings.

On the one hand, the maps are able to express the level of danger of the territory from different viewpoints (hydrogeological, seismic, due to landslides, pollution and so on).

On the other hand, the database provides a series of coordinated and coherent data related to features and state of conservation of the historical buildings - each of them geo-referred - and expresses a computable and objective evaluation of the level of vulnerability, derived by special algorithms.

\subsection{Historical centre assessment}

The combination of the values related to danger and vulnerability is at the base of the objective definition of heritage risk. This value may address intervention - and investments - to be promoted on cultural heritage, besides monitoring of intervention results: in one sentence, to have a scientific control of the procedures for a correct conservation maintenance.
The efficacy of the System mainly refers to:

-reliable and exhaustive definition of the different maps describing the territory;

- compliance of the data model, based on the selection of the architectural features to describe and on the assessment of the different levels of decay of the building components;

- development of the inference system defined by algorithms to work out the relative value of vulnerability and risk;

- adequate quantity of information about the historical building gathered by the platform.

During the last decades, the empowerment of the digital systems has been associated with the symmetric weakening of the central authorities, mainly due to the legislation overlapping of the national and regional competences related to cultural heritage and territory.

The enthusiasm for the new possibilities given by the advanced instruments and the need to collect data encouraged the development of autonomous systems, mainly related to regional contests.

Various Territorial Information Systems, especially related to the geo-portal of the regions Lombardy, Emilia Romagna, Latium, gather some geo-referred information about historical heritage. Although interesting and quite well developed, most of these systems were born rather in competition - not in continuity and without searching an interoperable way to work - with the original Risk Map, arousing their instability and incompleteness and compromising the possibility to converge in a shared and efficient system of control of the wealth state of our heritage.

Many of the new proposed Risk Maps - and the same 'original' Risk Map by MiBAC - defined different data models related to the different nature - or to specific issues - of the heritage considered.

After those about the 'traditional' historical monuments and buildings, new models have been defined to check the 
archaeological sites and the movable goods or to verify special forms of vulnerability, especially referred to the seismic risk (Accardo, 2000; Cacace, Ferroni, 2003; Angeletti, Bianchi, Cacace, Donatelli, Cristallini, Rasimelli, 2009).

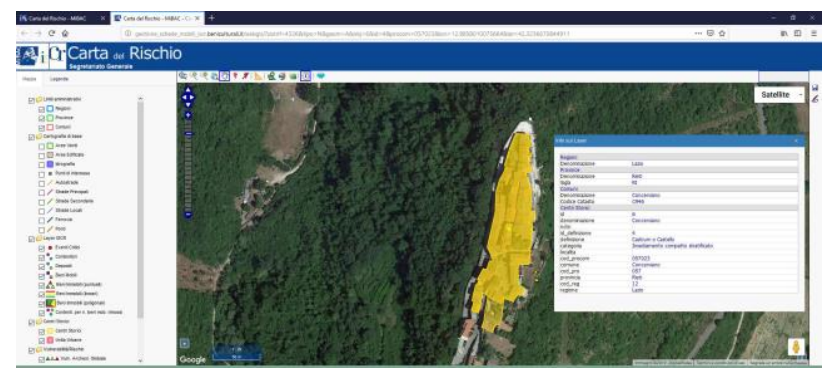

Figure 1. Risk Map: the historical center of Concerviano (Rieti) geoferred on the Satellite map with the general info of the database.

Among the others, the historical centres represent a special topic considered by some general proposals.

These proposals tried to describe the general issues and the possible way to organize data collection and risk assessment, from both the urban approach and the conservation viewpoint. In the former case, the cultural vision of the problems simply supported the organization of TIS with the possibility to relate some different maps, without a special and structured in depthanalysis of the architectural and building features of the historical town (Orlando 2008). In the latter, some attempts have been made, without defining an effective and working GIS (Geografic Information System) and following the organization of data given by the current 'traditional' urban planning (Bellini, Canevari, Marescotti, 1995).

\subsection{Risk map for historical centres}

A recent study and the digitalization of the historical centres have developed a completely new strategy for the conservation management of urban buildings through the 'Risk Map' of MiBAC. A dedicated book has wholly outlined Issues, aims and structure of the Territory Information System (TIS) describing the structure of the system according to historical framing of the debate and the previous experiences. The text illustrates the report models introduced, exemplifying the application of the system to some specific cases (Fiorani, 2019). Maps and digital report models are available within the current platform of the Carta del Rischio (http://www.cartadelrischio.it/ [20.2.2019]; Figg. 1-2).

We can synthetize here the main points laying at the core of the system:

- the description of the historical centres is multi scalar and is supported by six different report models. These are respectively related to: 1) Historical Center as a whole; 2) Urban Unit Aggregate (derived by the aggregation of different individual buildings inter-connected); 3) Urban Unit - Punctual Residential or Specialist Building (as hospital, school and similar); 4) Urban Space; 5) Building Unit; 6) Building Front;

- every report model is structured by a series of arguments, each of them described by a specific taxonomy derived by consolidated lexicons and studies;

- the assessment of several features, as use or decay, is based on the same rules of the previous report models of the MIBAC Risk Map, but an important innovation resides in the different appraising of sources of the vulnerability, related not only to decay but also to constructive weaknesses.

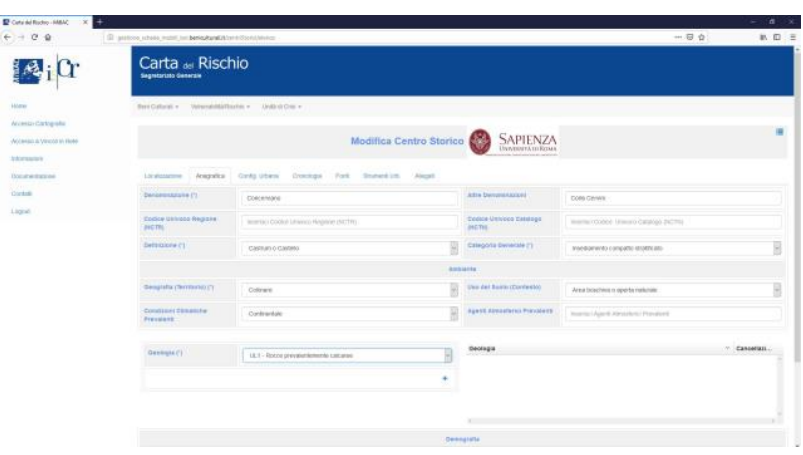

Figure 2. Risk Map: a sector of the report model concerning the identification record of the historical centre of Concerviano

(Rieti).

Six levels of 'incidences', corresponding to different spread percentage of the considered phenomenon, measure the weakness impact;

- vulnerability is considered at the scale of Urban Units and Building Units. Historical centre vulnerability is estimated by the average of the vulnerabilities of the single Urban Units existing within the centre. A specific index expresses vulnerability;

- a new index - related to transformation of the architectures was introduced to complete the historical centre assessment . This index is especially important to identify the level of change shown by the historical buildings, which is relevant for an effective vulnerability appraise (some transformation may hide discontinuities and decay just in the surfaces or may increase the level of weakness, introducing heterogeneous and not compatible structures);

- both vulnerability and transformation indexes derive from algorithms that work with the values of various 'incidences'. These incidences are specifically calculated in relation to the diffusion of the material and structural decay and to some spatial and technological building features that influence its behaviour.

As yet remembered, the use of the Risk Map is mainly oriented to give a hierarchy to the conservation intervention and to monitoring the state of conservation of historical buildings within the urban centre.

In addition, the set of information, the more detailed the more we go down in the level of report model, has a strong value by itself, allowing to institute matches among different sites, architectures, components, structures, materials and so on under different viewpoints.

Moreover, most of these data can be useful for other kind of digital elaboration: the description of some features, such as building typology, highness of the walls, distribution of the windows, type, distribution of structural decay and so on is at the basis of the studies and the conservation proposals.

The acquisition of data from the Risk Map platform is quite normal among GIS system, using the common informatics standards (Open Data, WMS, KML, GPX, SHP services).

The elaboration of a dedicated ontology will add the opportunity to make the same data available to other kind of software, beginning from HBIM Systems.

In this way, a synthetic description of the buildings, including the main features and the vulnerability and transformation index, will allow, through the $3 \mathrm{D}$ representation of the town, a stable monitoring of the urban tissue, constantly up to date with the new data deriving from the interventions gradually realized. 


\section{ONTOLOGIES FOR ARCHITECTURAI CONSERVATION}

To support conservation research and operational activity for historical urban contexts, management of heterogeneous and multidisciplinary information is a core issue. Moreover integration of information coming from different ITC sources is an important issue. Consequently, widespread proliferation of information systems and specialized lexicons are developing, although not definitely addressing at integrating different scopes but rather focussing on specificities, enhancing further incompatibilities. The research is oriented towards a system of representation based on ontologies aimed to overcome the difficulties of data integration and interchange among the various disciplinary sectors involved in conservation and management of cultural heritage (Doerr, 2001).

Complex problems of interaction between different, but complementary, information concerning historical centres may find, however, an effective support in formal conceptual representation as ontological models. The model structure adequately describes different cultural contexts and allow relations between different information systems. They constitute a language able to communicate either with the most known instruments for geographical representation, as GIS, either with environments addressed to architectural design and more generally to AEC (Architecture, Engineering, Construction), as BIM.

Some first researches have considered ontologies focused on cultural heritage domains without paying a special attention to architectural conservation issues and stressing mainly the inventory issues.

As an example, the Semantic Technologies for Archaeological Resources (STAR) project, addressed to archaeological sites documentation (May et al., 2011), the Architecture Metadata Object Schema (ARMOS), derived from CIDoc CRM for inventory of architectural objects (Agathos, Kapidakis, 2013), or the model by the Italian Ministry of the of cultural goods and activities Cultural-on, Ontologia dei luoghi della cultura e degli eventi culturali, conceived to identify the cultural site and giving information to the cultural events there organised (CULTURAL-ON: <http://dati.beniculturali.it/cis/> [20.7.2018]).

Other studies proposed a first synthetic - but probably too mechanical - approach to decay analysis of building materials, as MONDIS (Caciotti et al., 2015).

The model proposed to represent the Risk Map is conceived as a further development of the Conservation Process Model (CPM), specifically addressed to architectural conservation; this has been the first ontology particularly designed for architectural conservation process by the research group in Sapienza University of Rome.

The study of CPM has preliminarily taken into account the efficacy of the ontological model for architectural conservation (Acierno, 2017; Fiorani, 2017; Cacace, Bartolini, Talarico, Acierno, 2017; Caperna, Cutarelli, 2017; Fiorani, Acierno, 2017a). Subsequently it has addressed definitely formal modelling, focussing on the description of architecture and its investigation processes (Acierno, Cursi, Simeone, Fiorani, 2017; Simeone, Cursi, Acierno, 2019), on decay analysis and conservation design (Fiorani, Acierno, 2017b; Fiorani, Acierno, 2017c).

Pursuing the aim of enhancing a collaborative approach intended to integrate already existing effective systems rather than introducing new ones, the model has been conceived starting from an accurate analysis of the already existing ontologies already developed for cultural heritage purposes. As a result of this preliminary phase, CIDOC CRM has been identified as fully compliant to architectural conservation requirements, as it employs a formal language highly specialized, able to express relations between physical and abstract concepts referred to time or space, addressing therefore the true nature of conservation issues. CRM, which has become a standard ISO 21127 in 2006, has been developed to represent knowledge about museum management. Further scientific contexts have been considered through several extension models addressed to archaeological research (CRMarcheo and CRMba), geography (CRMgeo), scientific observation (CRMsci) and support to scientific argumentation (CRMinf) (Doerr, 2009, Crofts et al., 2010).

The new model has been therefore formalized starting from the core model of CIDOC-CRM (http://www.cidoccrm.org/Version/version-6.2.3 [25/02/19]), which fits the fundamental requirements for research (investigation, description, interpretation) and, more specifically, for storage of objects within museums. It presents four main domains, developed, either employing CRM classes and properties conceiving CRM subclasses or sub-properties or, when necessary, introducing new classes from scratch. CRM classes and properties are named as in the source model, while new entities introduced by CPM are identified with the name preceded by a prefix constituted by a group of letters 'Ecpm'for classes - and 'Pcpm'- for properties - and a progressive number. The formalized domains address the description of the building, the investigation process finalized to the conservation project, the actors involved and the building life cycle (referred either to its historical construction phases and transformation or to the conservation and maintaining project).

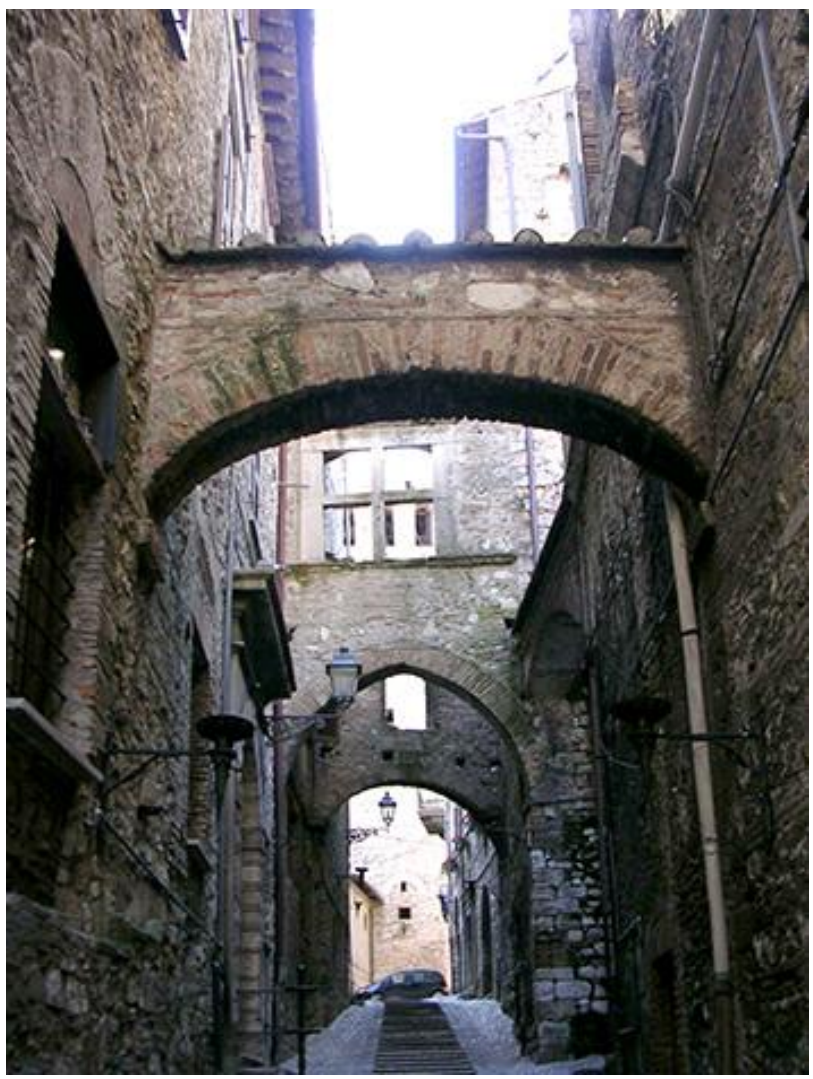

Figure 3. Historical centre of Narni (Terni): overview. 


\subsection{Modelling Risk Map for historical centres}

The described process has developed from the necessity to describe properly architectural object and conservation methodology. The definition of the ontology for Risk Map had to match with the existing structure of the ITS platform involving criteria for the evaluation of vulnerability.

The definition of the six report models for the historical centre has involved, from the beginning, the check of compliance between the report model articulation and the efficacy of formal representation.

To model Risk Map for historical centres, an extension of the model has been required to make the representation coherent with urban conservation and risk prevention scopes. Facing a manifold scope concerning either geographical or cultural aspects, the framework the model for Risk Map refers to is quite complex and necessarily looks both at geographical and cultural heritage ontologies.

Within geographical context, ontologies have had a wide spread due to the parallel development of web and Territorial Information Systems (TIS), especially GIS. A wide range of models has been proposed that may be classified into three principal types, fitted to different scopes: physical and natural, anthropic and geomatics, topographical and geometrical issues (Tambassi, Magro, 2015). Physical and natural framework aims at representing earth natural phenomena; anthropic issues refer to political, administrative and economical geography, finally, GTG (Geomatic - Topography - Geometry) systems focus on coordinating formalization between traditional representation as maps and charters and GIS or GPS environments. The latter are the most wide spread, although the most well-known has been developed by the Open Geospatial Consortium (OGC), the 'GeoSPARQL', it allows to produce reliable geometrical representation and to insert topological benchmarks. In addition to 'GeoSPARQL' other models should be considered as Geography Markup Language (GML) - ISO 19136 e il WGS84 Geo positioning; Geometry (Ordinance Survey).

A first formalization of the Risk Map for historical centres has been already developed with regard to the historical centre report model (Acierno, 2019). Instead of describing the whole formalization of the report model that has been widely explained in the cited paper, an overview of some of the main issues managed within the scope is here illustrated.

The multi scalar definition of the historical centre, through six levels of representation, required to extend the already formalized domain 'artefact' to address urban contents. Previously, the domain aimed at the representation of the architectural scale of the urban components, not focussing on the issues related to the building tissue, open spaces and the settlement as a whole.

The CRMba 'B1 Built work', whose declaratory definition is "This class comprises instances of man-made things such as freestanding buildings, components of buildings, and complexes of buildings. It refers to man-made environments, typically large enough for humans to enter, serving a practical purpose, being relatively permanent and stable", has proved to be compliant to architectural scope. Its specificities are also expressed by the hierarchical relations existing with the CRMcore super classes 'E24 Physical man made thing' and 'E 92 Space-time volume', where the first clarifies the anthropic origin and the second the fourth-dimensional nature of architectural entities. Although, the described features are not exhaustively representative for urban scope and a new class had to be formalized.

Regarding geographical and administrative information, the CRMgeo model proves to be compliant as it merges geographical and spatiotemporal properties of existing entities. Actually the 'SP2 Phenomenal Place' class, introduced by CRMgeo as a subclass of CRMcore 'E53 Place' is defined as comprising "instances of E53 Place [...] whose extent $[\ldots]$ and position is defined by the spatial projection of the spatiotemporal extent of a real world phenomenon that can be observed or measured".

This definition proves to adequately describe the entity 'historical centre', considering it a result of the anthropic phenomenon developed through time in a given territory; however, it doesn't describe other urban features as, for example, building tissue or road system.

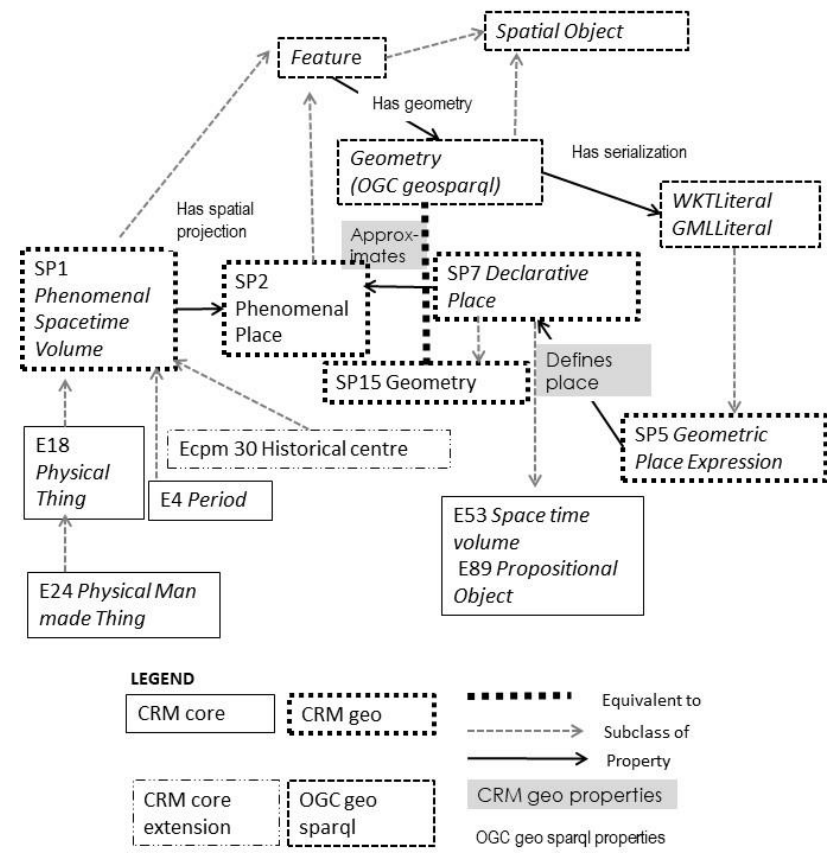

Figure 3. General schema of the relations between CIDOC and OGC models considered to develop CPM model.

Consequently, to integrate and complete the representation, a new class has been introduced 'Ecpm 30 Historical centre' conceived as a sub class of 'SP2 Phenomenal Place', from which it inherits all properties.

The whole definition from CRMgeo is: "This class comprises instances of E53 Place (S) whose extent (U) and position is defined by the spatial projection of the spatiotemporal extent of a real world phenomenon that can be observed or measured. The spatial projection depends on the instance of 'SP3 Reference Space' onto which the extent of the phenomenon is projected" (Fig. 3).

As a matter of fact, the Risk Map report introduces a further structure to analyse historical centres, referring to all its urban components that are divided into two main categories: built elements and open spaces. The first category gathers urban aggregates and isolated buildings, the latter refers to cultural heritage open spaces, cultural heritage urban landscapes and urban spaces.

Built elements are modelled through the class 'Ecpm 62 Urban Unit,' conceived as a sub class of the CRMba 'B1 built work', whereas open spaces are represented with the class 'open air spaces' introduced as a subclass of the CRMcore 'E22 Man made object'. All the urban component classes are related to the class 'Ecpm 30 Historical centre' through the property ' P48 consists of' (Fig. 4 ). 
One of the main topics the report deals with refers to taxonomy. The Risk Map refers to already consolidated lexicons defined by ICCD and ISCR that are widely recognized. The first, in particular, is at the core of one of the most known and shared vocabularies in the world, the Art \&Architecture Thesaurus (AAT), as the Italian Institute is one of its main contributors (www.getty.edu/research/tools/vocabularies/aat/ind ex.html, [25/02/19]). The report uses various taxonomies to describe properly urban architecture building features and decay phenomena. These are formalized through the class of CIDOC CRMcore 'E55 Type' and the related property 'P2 has type'. Decay assessment is developed through four different evaluations focussing on constructive vulnerability survey,

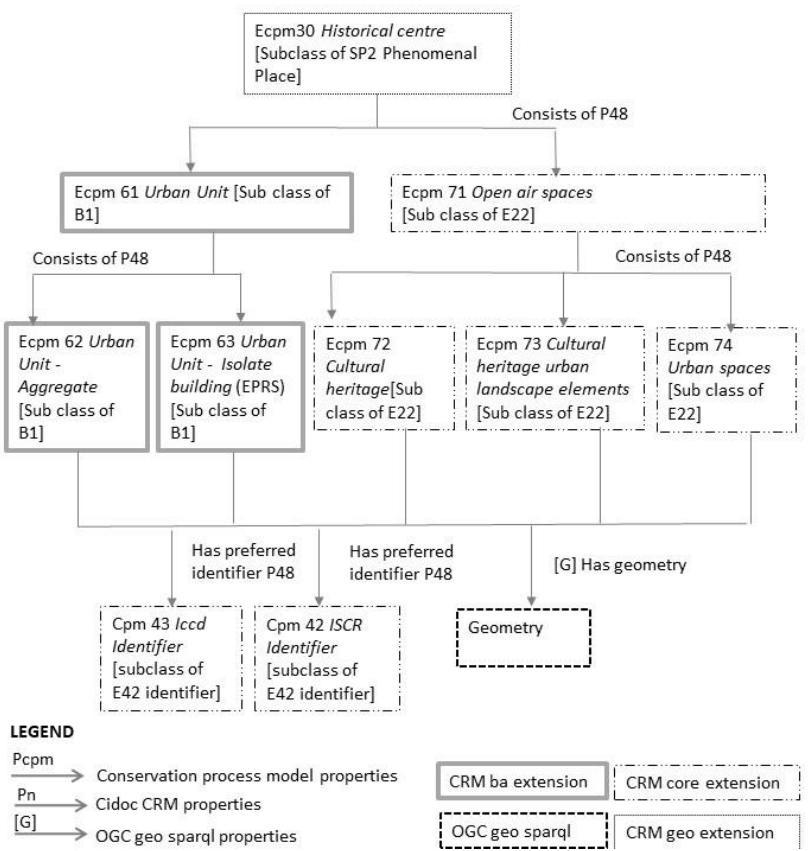

Figure 4. Classes and properties proposed to formalize the urban structure.

structural, superficial and roofs decay, which are represented by means of subclasses of the main class 'E14 Condition assessment'. Getting forward on modelling, the class 'E3 Condition state' will express the assessment results, whose activity is described with the CRMcore property 'P35 has identified'. Transformation assessment, which takes into account modern constructive elements, super-elevations, substitutions and repairs, has been modelled introducing the class 'Ecpm145 Modification assessment' as a subclass of 'E14 Condition assessment'.

To represent the surveyed phenomena incidence and their vulnerability and transformation incidence the model has mainly considered ontologies developed for representation of scientific investigation processes as CRMsci and CRMinf. Decay and transformations are conceived as CRMsci 'S15 Observable entities'. Their assessment is represented through a measuring activity described as 'E16 Measurement' and calculates the ratio between the numbers of floors involved in the considered phenomenon and the total number of existing floors.

The result obtained is described through the CRMcore 'E59 primitive value' and corresponds to a number. An algorithm allows to work out vulnerability and transformation indexes, taking into account the values obtained through the class 'E59 primitive value'. From the modelling point of view the algorithm is described as an inference making and formalized with the class CRMinf 'I3 Inference logic', whose result is obtained through the activity represented by the class 'S5 Inference Making' (Fig. 5). The definition of this class is "This class comprises the action of making honest propositions and statements about particular states of affairs in reality or in possible realities or categorical descriptions of reality by using inferences from other statements based on hypotheses and any form of formal or informal logic. It includes evaluations, calculations, and interpretations based on mathematical formulations and propositions".

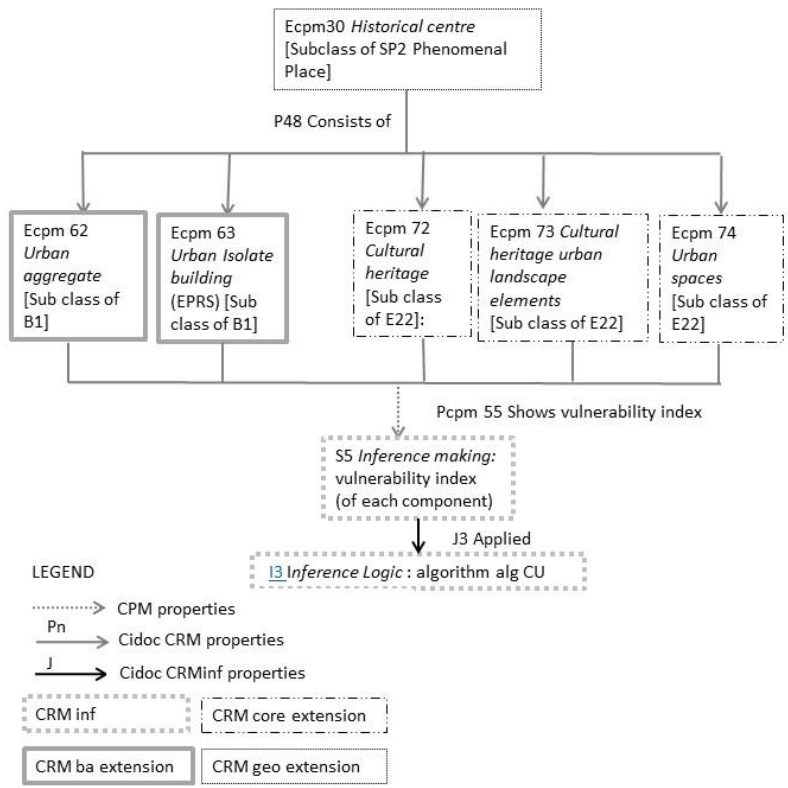

Figure 5. An algorithm works out the vulnerability index elaborating information retrieved from each urban component

\section{CONCLUSION}

Aiming at developing an instrument that may trigger a working process, able to merge territorial and architectural representation together with conservation and transformation issues, the present research develops and ontological model based on Cidoc Crm core model. The cases of formalization here exampled help to frame the general work done to connect the level of the territorial management to the level of the architectural conservation. A complete declaratory report of classes and properties is currently in progress: we consider this step an important next milestone of research on digitalization for conservation. Besides the publication of the CPM model, such a declaratory aims at enhancing collaboration and further extensions to other neighbouring scientific contexts.

\section{REFERENCES}

Accardo, G., 2000. La schedatura conservativa: esperienze dell'ICR in relazione alla Carta del Rischio, Morelli, C., Plances, E., Sattalini, F. (ed.). Atti del Primo seminario sulla catalogazione (Roma, 24-16 novembre 1999), ICCD, Roma, 34-45

Acierno, M., 2017. Un modello di rappresentazione per il restauro. Il caso dell'oratorio di San Saba a Roma, in 
Modellazione e gestione delle informazioni per il patrimonio edilizio esistente Della Torre S. (ed.), Galazzano Repubblica San Marino, Edizioni IMReady, http://www.ingenioweb.it/Sfogliabile/ReportageBHIMM2017/index.html [30/1/2019].

Acierno, M., 2019. Ontologie per i centri storici, in Fiorani, D., (ed.), Il futuro dei centri storici. Digitalizzazione e strategia, Quasar, Roma, 179-188.

Acierno, M., Cursi, S., Simeone, D., Fiorani, D., 2017. Architectural Heritage Knowledge Modelling: An OntologyBased Framework for Conservation Process. Journal of Cultural Heritage, 24, 124-133.

Agathos, M., Kapidakis, S., 2013. A Meta-Model Agreement for Architectural Heritage, Metadata and Semantics Research vol. 390. Springer, Thessaloniki, 384-395, https://doi.org/10.1007/978-3-319-03437-9_37 [30/1/2019].

Angeletti, P., Bianchi, A., Cacace, C., Donatelli, A., Cristallini, O., Rasimelli, E., 2009. Un metodo speditivo di valutazione della vulnerabilità e del rischio sismico di beni culturali. Caso di studio: Sicilia e Calabria, L'Ingegneria Sismica in Italia, Atti del XIII Convegno Nazionale ANIDIS (Bologna, 28 giugno-2 luglio), 2 sessione 4.1, pubblicazione CDrom.

Bellini, A., Canevari, A., Marescotti, L.,1995. Territorio, Beni culturali, piano. Il censimento dei beni architettonici: un'esperienza in Lombardia, Giambruno, M., Mascione M. (ed.), Alinea, Firenze.

Cacace, C., Ferroni, A., 2003. Carta del Rischio: La vulnerabilità Archeologica, in Apparati Musivi Antichi nell'area del Mediterraneo, Atti del Convegno internazionale di studi (Piazza Armerina, 9-13 aprile 2003), Quaderni di Palazzo Montalbo n. 4, Dario Flaccovio, Palermo, 466-472.

Carta del Rischio del Patrimonio Culturale, 1996. Ufficio centrale per i beni archeologici, artistici e storici - ICR, Roma.

Cacace, C., Bartolini, M., Talarico, F., Acierno, M., 2017. I fattori microclimatici, chimico-fisici e biologici: gestione e modellazione, in Modellazione e gestione delle informazioni per il patrimonio edilizio esistente, Della Torre 2017.

Cacciotti, R., Blasko, M,. Valach, J., 2015. A diagnostic ontological model for damages to historical constructions. Journal of Cultural Heritage, 16, 40-48

Caperna, M., Cutarelli, S., 2017. Contenuti e metodi legati alla descrizione di un'architettura ipogea a Roma. Contributi per la modellazione della conoscenza in Modellazione e gestione delle informazioni per il patrimonio edilizio esistente, Della Torre 2017.

Castelli, G. (ed.), 1997. La Carta del Rischio del Patrimonio Culturale, ICR - Bonifica, Roma.

Le Boeuf, P., Doerr, M., Emil Ore, C., Stead, S., 2018. Definition of the CIDOC Conceptual Reference Model, version 6.2. 3, May 2018 - http://www.cidoc-crm.org/ [30/1/2019].

Crofts, N., Doerr, M., Gill, T., Stead, S, Stiff, M., 2010 Definition of the CIDOC Conceptual Reference Model, ICOM/CIDOC Documentation Standards Group CIDOC CRM
Special Interest Group, 2010 http://www.cidoccrm.org/docs/cidoc crm version 5.0.2.pdf [30/1/2019].

Doerr, M., Kritsotaki, A., Rousakis, Y., Hiebel, G., Theodoridou, M., 2018. Definition of the CRMsci. An Extension of CIDOC-CRM to support scientific observation, version 1.2.5, May 2018 - http://www.cidoc-crm.org/crmsci/ [30/1/2019]-

Doerr, M., Felicetti, A., Hermon, S., Hiebel, G., Kritsotaki, A., Masur, A., May, K., Ronzino, P., Schmidle, W., Theodoridou, M., Tsiafaki, D., Christaki, E., Definition of the CRMarchaeo. An Extension of CIDOC CRM to support the archaeological excavation process, version 1.4.5, April 2018 http://www.cidoc-crm.org/crmarchaeo/ [30/1/2019]

Hiebel, G., Doerr, M., Eide, Ø., Theodoridou, M., 2015. A Spatiotemporal Model. An Extension of CIDOC-CRM to link the CIDOC CRM to GeoSPARQL through a Spatiotemporal Refinement, version 1.2, September 2015 - http://www.cidoccrm.org/crmgeo/ [30/1/2019].

Doerr, M., 2009. Ontologies for cultural heritage, in: S. Staab, R. Studer (Eds.), Hand-book on Ontologies, Springer, Berlin Heidelberg, 463-486.

Fiorani, D., 2017. La modellazione della conoscenza nel restauro: uno sviluppo per il BHIMM. Problematiche generali e il caso-studio di San Saba in Roma, in Modellazione e gestione delle informazioni per il patrimonio edilizio esistente Built Heritage Information Modelling/Management BHIMM, Della Torre 2017

Fiorani, D., 2019. Il futuro dei centri storici. Digitalizzazione e strategia, Quasar, Roma .

Fiorani, D., Acierno, M., 2017a. Drawing, information and design: tools and perspective for conservation. Ippolito A. (ed.), Handbook of Research on Emerging Technologies for Architectural and Archaeological Heritage, IGI Global, Hershey (Pennsylvania), 355-386.

Fiorani, D., Acierno, M., 2017b. Conservation process model (cpm): a twofold scientific research scope in the information modelling for cultural heritage, GEOMATICS \& RESTORATION - Conservation of Cultural Heritage in the Digital Era (Florence, Italy, 22-24 May 2017), "ISPRS. The International Archives of the Photogrammetry, Remote Sensing and Spatial Information Sciences", Volume XLII-5/W1, 283290.

Fiorani, D., Acierno M., 2017c. CPM. Un'Ontologia per il Restauro, Ananke, n.s., Numero Speciale Geores, 141-146.

May, K. , Binding, C., Tudhope, D., 2011. A STAR is Born: Some Emerging Semantic Technologies for Archaeological Resources. On the Road to Reconstructing the Past. Computer Applications and Quantitative Methods in Archaeology (CAA), Archaeolingua, Budapest, 111-116 http://proceedings.caaconference.org/paper/cd53_may_et_al_ca a2008/ [30/1/2019].

Orlando, M., 2008. Il ruolo dei Sistemi informativi territoriali nel processo di recupero, Franco Angeli, Milano.

Ronzino, P., Niccolucci, F., Felicetti, A., Doerr, M., Definition of the CRMba. An extension of CIDOC CRM to support 
buildings archaeology documentation, version 1.4, December 2016 http://www.cidoc-crm.org/crmba/ [30/1/2019]

Simeone, D., Cursi, S., Acierno, M., 2019. BIM semanticenrichment for built heritage representation, Automation in Construction, 97, 122-137.

Stead, S., Doerr M., CRMinf: the Argumentation Model. An Extension of CIDOC-CRM to support argumentation, version 0.7, February 2015 - http://www.cidoc-crm.org/crminf/ [30/1/2019].

Tambassi, T., Magro, D., 2015. Ontologie informatiche della geografia. Una sistematizzazione del dibattito contemporaneo. Rivista di estetica, 58, 191-205 